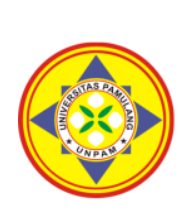

\title{
PENGARUH HARGA DAN PROMOSI TERHADAP KEPUTUSAN PEMBELIAN SMARTPHONE OPPO PADA OUTLET HAPPY CELL PAMULANG - TANGERANG SELATAN
}

\author{
${ }^{1}$ Nani Widia, ${ }^{2 *}$ Wahyu Nurul Faroh \\ Universitas Pamulang, Tangerang, Banten, Indonesia \\ *dosen01061@unpam.ac.id
}

\begin{abstract}
Abstrak
Penelitian ini bertujuan untuk mengetahui pengaruh harga dan promosi terhadap keputusan pembelian smartphone oppo pada outlet happy cell area pamulang. Jenis penelitian yaitu asosiatif dengan pendekatan deskriptif dan kuantitatif. Metode yang digunakan untuk menguji dan menganalisis pengaruh secara parsial dan simultan dengan menggunakan analisis regresi, koefisien korelasi, koefisien determinasi, uji $\mathrm{t}$ dan uji $\mathrm{f}$. Berdasarkan hasil penelitian harga berpengaruh positif dan signifikan terhadap keputusan pembelian dimana diperoleh nilai $(6,138>1,677)$ dan sig $(0,000<0,05)$ dengan demikian H0 ditolak dan Ha. Dan promosi berpengaruh positif dan signifikan terhadap keputusan pembelian dimana diperoleh nilai $(3,707>1.677)$ dan sig $(0,001<0,05)$ dengan demikian H0 ditolak dan Ha diterima. Dengan demikian dapat disimpulkan dari pengujian hipotesis menggunakan uji statistik dengan nilai $(19,736>3,20)$, dan hal tersebut juga diperkuat dengan signifikansi $0,000<0,05$. Dengan demikian $\mathrm{H0}$ ditolak dan Ha diterima.

Kata Kunci: Harga, Promosi dan Keputusan Pembelian

Abstract
This study aims to determine the effect of price and promotion on purchasing decisions for Oppo smartphones at happy cell outlets in the Pamulang area. The type of research is associative with descriptive and quantitative approaches. The method used to test and analyze the effect partially and simultaneously using regression analysis, correlation coefficient, coefficient of determination, $t$ test and $f$ test. Based on the results of the research, the price has a positive and significant effect on purchasing decisions where the values obtained $(6.138>1.677)$ and sig $(0.000<0.05)$ thus $\mathrm{HO}$ is rejected and Ha. And promotion has a positive and significant effect on purchasing decisions where the values obtained $(3.707>1.677)$ and sig $(0.001<0.05)$ thus $\mathrm{HO}$ is rejected and $\mathrm{Ha}$ is accepted. Thus, it can be concluded from hypothesis testing using statistical tests with a value of (19.736> 3.20), and this is also strengthened by a significance of $0.000<0.05$. Thus HO is rejected and Ha is accepted.
\end{abstract}

Keywords: Price, Promotion and Purchase Decision

\section{PENDAHULUAN}

Perkembangan teknologi di indonesia saat ini semakin cepat seiring dengan penemuan dan pengembangan ilmu pengetahuan, salah satunya dalam bidang informasi dan komunikasi sehingga dapat menciptakan alat-alat yang mendukung perkembangan teknologi informasi maupun komunikasi. Saat ini media komunikasi di indonesia juga semakin canggih dan juga tidak bisa dihindarkan dalam kehidupan masyarakat, dengan media komunikasi yaitu smartphone untuk zaman sekarang ini sangat diperlukan oleh semua kalangan masyarakat bahkan untuk sebagian masyarakat pada saat ini smartphone merupakan salah satu kebutuhan primer. Karena perkembangan teknologi informasi dan komunikasi yang sangat pesat maka smartphone untuk saat ini bukan hanya digunakan sebagai alat komunikasi saja namun juga sebagai trend ataupun gaya hidup masyarakat, banyaknya masyarakat yang menggunakan smartphone maka banyak pula produsenprodusen smartphone bermunculan dengan menawarkan produk mereka 
dengan berbagai macam kelebihan fiturfiturnya seperti dilengkapi dengan kamera, pemutar video, akses internet, dan juga aplikasi-aplikasi yang bisa di download sesuai kebutuhan dan keinginan si pengguna smartphone.

Di indonesia sendiri banyak produsen smartphone yang menawarkan smartphone dengan berbagai macam fitur salah satunya adalah Oppo. Oppo yang sebelumnya memproduksi peralatan elektronik seperti MP3 player, LCD TV, portable media player, DVD, ebook, dan barulah pada tahun 2008 Oppo memproduksi smartphone yang memiliki banyak fitur dan juga kelebihan yang memudahkan si penggunanya, walaupun sebelumnya lebih dulu dipasarkan akan tetapi oppo mampu bersaing dalam memasarkan produknya. Selain itu, agar sukses dalam memasarkan suatu barang atau jasa setiap produsen harus dapat menetapkan harganya secara tepat. Happy cell merupakan sebuah outlet penjualan berbagai macam smartphone salah satunya produk smartphone oppo. Tingginya permintaan terhadap produk smartphone oppo dipengaruhi oleh faktor pendapatan masyarakat itu sendiri. Pendapatan yang semakin baik atau menurun membuat masyarakat ingin mendapatkan suatu barang seperti smartphone yang berkualitas dan harga terjangkau. Berikut adalah tabel harga beberapa tipe smartphone oppo dengan beberapa tipe harga smartphone xiaomi.

Tabel 1. Harga Smartphone Oppo

\begin{tabular}{|c|c|}
\hline \multicolumn{2}{|c|}{ Smartphone Oppo } \\
\hline Tipe & Harga \\
\hline Oppo Reno 5 & Rp. 4.999.999 \\
\hline Oppo Reno 4 & Rp. 4.199.000 \\
\hline Oppo Reno 4 F & Rp. 3.999.000 \\
\hline Oppo A92 & Rp. 3.799.000 \\
\hline Oppo A53 & Rp. 2.499.000 \\
\hline Oppo A15 & Rp. 2.299.000 \\
\hline
\end{tabular}

Sumber: Smartphone Oppo Indonesia

Berikut tabel penjualan smartphone oppo pada outlet happy cell. Penulis
Tabel 2. Tabel Smartphone Xiaomi

\begin{tabular}{|c|c|}
\hline \multicolumn{2}{|c|}{ Smartphone Xiaomi } \\
\hline Tipe & Harga \\
\hline Mi 10T & Rp. 4.999.000 \\
\hline Redmi Note 10 Pro & Rp. 3.499.000 \\
\hline Poco X3 NFC & Rp. 3.099.000 \\
\hline Redmi Note 10 & Rp. 2.399.000 \\
\hline Redmi 9T & Rp. 2.299.000 \\
\hline Poco M3 & RP. 1.799.000 \\
\hline
\end{tabular}

Dari tabel diatas menjelaskan bahwa harga yang ditawarkan produk smartphone oppo memang memiliki beberapa tipe yang harganya relatif mahal dari pada kompetitornya. Tetapi selain harga yang menjadi perhatian konsumen yaitu adanya promosi. Promosi dapat menarik minat konsumen supaya membeli dan menggunakan smartphone oppo. Aktivitas promosi tertumpu kepada membuat tawaran seperti tawaran potongan harga, jualan murah dan lain-lain. Berikut adalah tabel promosi yang ada pada outlet happy cell.

Tabel 3. Promosi Pada Outlet Happy Cell

\begin{tabular}{|c|c|}
\hline $\begin{array}{c}\text { Nikmati Promo dengan } \\
\text { Kredivo } \\
\text { Bunga Bisa 0\% } \\
\text { Tenor : 7 Bulan dan 10 }\end{array}$ & Periode 22 Juli - 31 \\
Agust 2020 \\
\hline Cashback up to \\
Rp.1.500.000 & Periode 01 - 31 \\
Pembelian cash & Oktober 2020 \\
\hline Promo Jelang Akhir & \\
Tahun 'Year-End' & Periode bulan \\
Harga smartphone & 23 nov - 31 Des 2020 \\
dibanderol bersahabat & \\
\hline
\end{tabular}

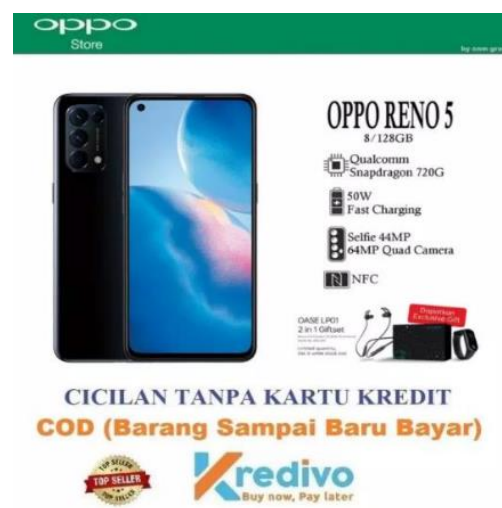

Gambar 1. Smartphone Oppo Reno 5

meneliti data penjualan dari bulan juli sampai dengan november 2020. 
Tabel 4. Penjualan Smartphone Periode Bulan Juli s/d Nov 2020

\begin{tabular}{|c|c|c|c|c|c|c|c|}
\hline \multirow[b]{2}{*}{ No } & \multirow[b]{2}{*}{ Nama Tipe } & \multicolumn{5}{|c|}{ Target 75 Item/bulan } & \multirow[b]{2}{*}{ Total } \\
\hline & & Jul-20 & Agt-20 & Sep-20 & Okt-20 & Nov-20 & \\
\hline 1 & Oppo & 25 & 14 & 14 & 20 & 11 & 84 \\
\hline 2 & Samsung & 22 & 23 & 11 & 15 & 11 & 82 \\
\hline 3 & Xiaomi & 15 & 13 & 20 & 23 & 15 & 86 \\
\hline 4 & Vivo & 15 & 13 & 16 & 17 & 5 & 66 \\
\hline & Total & 77 & 63 & 61 & 75 & 42 & 318 \\
\hline \multicolumn{2}{|c|}{ Persentase (\%) } & $103 \%$ & $84 \%$ & $88 \%$ & $100 \%$ & $56 \%$ & \\
\hline \multicolumn{2}{|c|}{ Keterangan } & $\begin{array}{c}\text { Mencapai } \\
\text { Target }\end{array}$ & $\begin{array}{c}\text { Tidak } \\
\text { Mencapai } \\
\text { Target }\end{array}$ & $\begin{array}{c}\text { Tidak } \\
\text { Mencapai } \\
\text { Target }\end{array}$ & $\begin{array}{c}\text { Mencapai } \\
\text { Target }\end{array}$ & $\begin{array}{c}\text { Tidak } \\
\text { Mencapai } \\
\text { Target }\end{array}$ & \\
\hline
\end{tabular}

Sumber: Outlet Happy Cell Pamulang

Berdasarkan data tabel diatas menunjukkan bahwa total penjualan smartphone oppo dari bulan juli sampai dengan november 2020 mengalami penjualan yang fluktuatif. Target setiap bulannya manajemen menetapkan target penjualan harapannya mampu dicapai $100 \%$. Namun dari data tersebut penjualan smartphone oppo bulan november mengalami penurunan berjumlah 11 unit dan belum mencapai target yang diharapkan.

\section{TINJAUAN PUSTAKA}

\section{Harga}

Menurut Deliyanti Oentoro, di dalam Sudaryono (2016:216) "harga adalah suatu nilai tukar yang bisa disamakan dengan uang atau barang lain untuk manfaat yang diperoleh dari suatu barang atau jasa bagi seseorang atau kelompok pada waktu tertentu dan tempat tertentu". Menurut Suparyanto dan Rosad (2015:141) "Harga adalah jumlah sesuatu yang memiliki nilai pada umumnya berupa uang yang harus dikorbankan untuk mendapatkan suatu produk. Dari berbagai pendapat diatas penulis menyimpulkan bahwa harga diartikan sebagai suatu nilai tukar yang bisa dibeli dengan uang untuk mendapatakan barang atau jasa.

2. Promosi

Kedisiplinan merupakan fungsi Menurut Kotler dan Keller (2016:47) "promosi merupakan aktivitas yang mengkomunikasikan keunggulan produk dan membujuk pelanggan sasaran untuk membelinya". Menurut William Shoell yang dikutip oleh Alma (2013:179) bahwa "Promosi ialah usaha yang dilakukan oleh marketer untuk berkomunikasi dengan calon pelanggan". Dari kedua pengertian diatas maka dapat disimpulkan bahwa kegiatan promosi adalah suatu kegiatan komunikasi antara pembeli dan penjual mengenai keberadaan produk dan jasa, menyakinkan, membujuk dan meningkatakn kembali akan produk dan jasa tersebut sehingga mempengaruhi sikap dan perilaku yang mendorong kepada pertukaran dalam pemasaran.

3. Keputusan Pembelian

Menurut Tjiptono (2016:22) "Keputusan pembelian merupakan salah satu bagian dari perilaku konsumen. Perilaku konsumen merupakan tindakan yang secara langsung terlibat dalam usaha memperoleh, menentukan produk dan jasa, termasuk proses pengambilan keputusan yang mendahului dan mengikuti tindakan tersebut".

\section{METODE}

Penelitian ini merupakan penelitian asosiatif yaitu penelitian yang bertujuan untuk mengetahui pengaruh atau hubungan antara dua variabel atau lebih sekaligus penelitian deskriptif dengan pendekatan kuantitatif yaitu memberi gambaran yang teratur tentang suatu kejadian dan akan dibahas dalam menganalisa data kuantitatif (data yang 
bersifat angka). Populasi dalam penelitian ini adalah konsumen yang membeli smartphone oppo, sebanyak 50 (lima Puluh) orang. Pengambilan sampel menggunakan metode sampling jenuh. Menurut Sugiyono (2018:122) "sampel jenuh adalah teknik penentuan sampel bila semua anggota populasi digunakan sebagai sampel. Hal ini sering dilakukan bila jumlah populasi relatif kecil yang subjeknya tidak mencapai 100 (seratus) responden". Oleh karena itu sampel pada penelitian ini berjumlah 50 (lima Puluh) orang. Teknik analisis data menggunakan uji deskriptif, uji regresi berganda, koefisien korelasi, koefisien determinasi, dan uji hipotesis/uji signifikansi $\mathrm{t}$ dan $\mathrm{f}$.

\section{HASIL DAN PEMBAHASAN}

1. Pembahasan Hasil Penelitian

Berdasarkan hasil penelitian yang telah diuraikan sebelumnya menunjukkan bahwa terdapat pengaruh positif dan signifikan baik secara parsial maupun simultan harga dan promosi terhadap keputusan pembelian. Berikut ini dipaparkan penjelasan atas jawaban dari hipotesis penelitian.

a. Pengaruh Harga (X1) Terhadap Keputusan Pembelian (Y)

Berdasarkan hasil penelitian ini didapatkan bahwa variable Harga (X1) memiliki pengaruh terhadap Keputusan Pembelian (Y) pada outlet happy cell. Pengaruh harga terhadap keputusa pembelian dapat dijelaskan dengan beberapa faktor. Hasil penelitian uji hipotesis diperoleh nilai $\mathrm{t}$ hitung $>\mathrm{t}$ tabel atau $(6,138>1,677)$ dan sig $(0,000<0,05)$ dengan demikian $\mathrm{H} 0$ ditolak dan Ha diterima artinya terdapat pengaruh yang positif dan signifikan secara parsial antara harga terhadap keputusan pembelian pada outlet happy cell.

b. Pengaruh Promosi (X1) Terhadap Keputusan Pembelian (Y)

Berdasarkan hasil pengujian hipotesis kedua yang telah dilakukan, didapatkan bahwa variable Promosi (X2) memiliki pengaruh terhadap
Keputusan Pembelian (Y) pada outlet happy cell. Dapat dilihat dari 2 .

Dari Pengujian Hipotesis Promosi diperoleh nilai $\mathrm{t}$ hitung $>\mathrm{t}$ tabel atau $(3,707>1.677)$ dan sig $(0,001<0,05)$ dengan demikian $\mathrm{HO}$ ditolak dan $\mathrm{Ha}$ diterima artinya terdapat pengaruh yang positif dan signifikan secara parsial antara promosi terhadap keputusan pembelian smartphone pada outlet happy cell. Hasil pengujian ini sejalan dengan beberapa penelitian terdahulu.

c. Pengaruh Harga (X1) dan Promosi (X2) Secara Simultan Terhadap Keputusan Pembelian (Y) Hasil penelitian ini menunjukkan bahwa Harga (X1) dan Promosi (X2) berpengaruh positif Terhadap Keputusan Pembelian (Y). Berdasarkan hasil penelitian, pengujian hipotesis menggunakan uji statistik diperoleh nilai $\mathrm{f}$ hitung $>\mathrm{f}$ tabel atau $(19,736>3,20)$, dan hal tersebut juga diperkuat dengan signifikansi 0,000<0,05. Dengan demikian $\mathrm{H} 0$ ditolak dan $\mathrm{Ha}$ diterima. Artinya terdapat pengaruh positif dan signifikan secara simultan antara harga dan promosi terhadap keputusan pembelian smartphone oppo pada outlet happy cell.

\section{PENUTUP \\ Simpulan}

Berdasarkan hasil penelitian, serangkai pengolahan data dan analisis serta pembahasan mengenai "Pengaruh Harga dan Promosi Terhadap Keputusan Pembelian Smartphone Oppo Pada Outlet Happy Cell Pamulang - Tangerang Selatan", maka dapat ditarik beberapa kesimpulan, yaitu:

1. Dari Pengujian Hipotesis Harga diperoleh nilai $\mathrm{t}$ hitung $>\mathrm{t}$ tabel atau $(6,138>1,677)$ dan sig $(0,000<0,05)$ dengan demikian $\mathrm{HO}$ ditolak dan $\mathrm{Ha}$ diterima artinya terdapat pengaruh yang positif dan signifikan secara parsial antara harga terhadap keputusan pembelian. 
2. Dari Pengujian Hipotesis Promosi diperoleh nilai $\mathrm{t}$ hitung $>\mathrm{t}$ tabel atau $(3,707>1.677)$ dan sig $(0,001<0,05)$ dengan demikian $\mathrm{H} 0$ ditolak dan $\mathrm{Ha}$ diterima artinya terdapat pengaruh yang positif dan signifikan secara parsial antara promosi terhadap keputusan pembelian.

3. Berdasarkan hasil penelitian, pengujian hipotesis menggunakan uji statistik diperoleh nilai $\mathrm{f}$ hitung $>\mathrm{f}$ tabel atau $(19,736>3,20)$, dan hal tersebut juga diperkuat dengan signifikansi $0,000<0,05$. Dengan demikian H0 ditolak dan Ha diterima. Artinya terdapat pengaruh positif dan signifikan secara simultan antara harga dan promosi terhadap keputusan pembelian smartphone oppo pada outlet happy cell.

\section{Saran}

Berdasarkan kesimpulan yang diperoleh dari penelitian ini, maka diajukan saran-saran sebagai pelengkap terhadap hasil penelitian sebagai berikut:

1. Pada variabel X1 (Harga) indikator kesesuaian harga dengan kualitas produk, masih ada 1 orang yang tidak setuju pada pernyatan "Harga dengan kualitas produk smartphone oppo sesuai dengan yang ditawarkan oleh wiraniaga pada outlet happy cell". Maka disarankan kepada outlet happy cell untuk menerapkan harga yang sesuai dengan tipe dan kualitas smartphone oppo.

2. Pada variabel $X 2$ (Promosi) indikator direct marketing (pemasaran langsung), masih ada 1 orang yang tidak setuju pada pernyatan "Adanya ketersediaan katalog produk smartphone oppo pada outlet happy cell". Maka disarankan kepada wiraniaga outlet happy cell pada saat menawarkan untuk memberikan katalog atau gambar-gambar tipe smartphone oppo agar konsumen lebih yakin dalam memilih produk smartphone oppo.

3. Pada variabel Y (Keputusan Pembelian) indikator pemilihan poduk, masih ada 1 orang yang tidak setuju pada pernyatan "Saya yakin membeli produk smartphone oppo di outlet happy cell". Maka disarankan kepada wiraniaga outlet happy cell untuk lebih merekomendasikan produk smartphone oppo karena lebih unggul dibadingkan produk smartphone lainnya kepada konsumen.

4. Berdasarkan tabel diatas dapat diketahui bahwa koefisien determinasi (R Square) yang diperoleh sebesar 0,456. Hal ini berarti 45,6\% Keputusan Pembelian dapat dijelaskan oleh variabel Harga (X1) dan Promosi (X2), sedangkan sisanya $54,4 \%$ Keputusan Pembelian dipengaruhi oleh bauran pemasaran (Marketing Mix) dimana bauran pemasaran merupakan variabelvariabel yang dapat dikontrol perusahaan dan dapat digunakan untuk mempengaruhi pasar. Adapun variabel-variabel lainnya yg mempengaruhi keputusan pembelian yaitu product, people, place, process, dan phsycal evidence. Maka disarankan kepada outlet happy cell untuk lebih memperhatikan dan menentukan strategi pemasaran yang efektif dan efisien dimasa mendatang mengingat konsumen sangat memperhatikan keputusan pembelian yang akan dijadikan asumsi bagi mereka.

\section{DAFTAR PUSTAKA}

Afriyansah, D. (2016). Pengaruh Harga dan Promosi Terhadap Kpeutusan Pembelian smarrtphone android xiaomi (Studi pada Komunitas Mi Fans Xiaomi Yogyakarta) (Studi pada Komunitas Mi Fans Xiaomi Yogyakarta) (Doctoral dissertation, UPN" Veteran" Yogyakarta).

Akbar, K., \& LATARUVA, E. (2013). Analisis Pengaruh Harga, Brand Image, dan Atribut Produk terhadap Keputusan Pembelian Handphone atau Smartphone Samsung Jenis Android (Studi pada Mahasiswa Universitas Diponegoro) (Doctoral dissertation, Fakultas Ekonomika dan Bisnis). 
Andis, A., Risal, M., \& Usman, H. (2019). Pengaruh Kualitas Produk, Harga dan Promosi terhadap Keputusan Pembelian Produk Handphone Samsung pada toko centro palopo. Jurnal Manajemen STIE Muhammadiyah Palopo, 5(1), 25-31.

Aristo, S. F. (2016). Pengaruh produk, harga, dan promosi terhadap keputusan pembelian konsumen woles chips. Jurnal Manajemen Dan Start-Up Bisnis, 1(4), 441-447.

Budiharja, R. G. E. (2016). Pengaruh Kualitas Produk, Harga, Promosi Dan Brand Image Terhadap Keputusan Pembelian Produk Aqua di Kota Pati. Jurnal STIE Semarang, 8(2).

Dharmayuni, L., et al.. (2021). Effect of Distribution Cost and Promotion Cost on Tyre Industries Sales Performance. Annals of the Romanian Society for Cell Biology, 12672-12684.

Erlangga, H. (2021). Effect Of Digital Marketing And Social Media On Purchase Intention Of Smes Food Products. Turkish Journal of Computer and Mathematics Education

Faroh, W. N. (2017). Analisa Pengaruh Harga, Promosi, Dan Pelayanan Terhadap Keputusan Pembelian. KREATIF: Jurnal Ilmiah Prodi Manajemen Universitas Pamulang, $4(2)$.

https://www.mi.co.id/id/index.html https://www.oppo.com/id/

Khusyairi, M. H. R., Lukiana, N., \& Hartono, H. (2018). Pengaruh Desain Produk, Positioning dan Word Of Mouth Terhadap Keputusan Pembelian Honda pada UD. Karunia Sejahtera Motor Lumajang. Jobman: Journal of Organization and Bussines Management, 1(1), 156-167.

Kotler \& Armstrong. (2011). Prinsip-Prinsip Pemasaran, terj. Ira USA: Pearson Education, 152.

Kotler, Philip and Kevin Lane Keller, 2016. Marketing Managemen, 15th Edition.

Margareta, L. C., \& Widyawati, N. (2019). Pengaruh Lokasi, Kualitas Pelayanan dan Promosi Terhadap Kepuasan
Konsumen Sate Taicha Goreng Cabang Surabaya. Jurnal Ilmu dan Riset Manajemen (JIRM), 8(7).

Martini, Y. (2016). Pengaruh Harga, Kualitas Produk, dan Promosi Terhadap Keputusan Pembelian Produk Smartphone Oppo di Area Internasional Plaza Palembang. Jurnal Kompetitif, 5(2), 53-64.

Mas'adi, M. (2020). Pengaruh Kegiatan Promosi Terhadap Keputusan Pembeian Pada PT. Indotex Mandiri di Tangerang. Jurnal Ekonomi Efektif, 3(1), 105-111.

Masrin, I., \& Yanto, R. P. (2019). Dampak Promosi, Harga Dan Citra Merek Terhadap Keputusan Pembelian Smartphone Oppo. Jurnal Sains Manajemen Dan Bisnis Indonesia, 9(1), 90-99.

Nurjaya, N., et al. (2020). Pengaruh Store Atmosphere Terhadap Keputusan Pembelian Konsumen Pada Starbucks Di Wilayah Cianjur. Jurnal Ekonomi Efektif, 2(4), 637-643.

Pasaribu, V. L. D. (2020). Analisis Pengaruh Promosi, Kualitas Produk dan Desain Kemasan Terhadap Keputusan Pembelian Hand and body Lotiomn Merek Citra (Studi Kasus Carrefour Pamulang, Tangerang Selatan). Jurnal Pemasaran Kompetitif, 1(4).

Priyambodo, G. (2014). Pengaruh Kualitas Produk, Harga dan Promosi Terhadap Keputusan Pembelian Handphone Merek Blackberry. Universitas Dian Nuswantoro. Semarang.

Rasyid, N., et al. (2018). Pengaruh Bauran Pemasaran Terhadap Penjualan Pada PT. Nestle Indofood Citarasa Indonesia Di Makassar. Sentralisasi, 7(2), 11-27

Setiawati, N. P. A., et al.. (2021). Effect of Technology Acceptance Factors, Website Service Quality and Specific Holdup Cost on Customer Loyalty: A Study in Marketing Departement of Packaging Industry. Annals of the Romanian Society for Cell Biology, 12685-12697. 
T. Hani Handoko. (2001). Manajemen, Yogyakarta: BP Fakultas Ekonomi, Cet. Ke- 17, h. 10

Tobing, M. D. (2018) Tobing, D. M. (2018). Pengaruh Citra Merek Terhadap Keputusan Pembelian Smartphone Oppo (Studi pada Mahasiswa Program Studi Manajemen S1 Fakultas Ekonomi Universitas Pamulang).

Wangsi, M. M., \& Rawi, R. D. P. (2018). Perlindungan Konsumen Dalam Pelabelan Produk Menurut Ekonomi Islam. Sentralisasi, 7(1), 1-9.
Wicaksono, A. W. (2017). Analisis Pengaruh Kualitas Produk, Harga dan Promosi Terhadap Keputusan Pembelian Handphone Merek Xiomi di Surakarta (Doctoral dissertation, Universitas Muhammadiyah Surakarta).

Yulistiana, I., et al.. (2021). Did Brand Perceived Quality, Image Product And Place Convenience Influence Customer Loyalty Through Unique Value Proposition?. Journal of Contemporary Issues in Business and Government, 27(1), 2854-2867. 